\title{
Rules of Conduct and Principles of Adjudication
}

\author{
Paul H. Robinson $\dagger$ \\ Table of Contents
}

I. Rules of Conduct and Principles of Adjudication: The Distinction and Its Implications .............

II. Rules of Conduct and Principles of Adjudication in Current Doctrine.................... 733

A. The Distinction Applied to Current Doctrine.. 733

1. Objective elements of an offense ........ 733

2. Secondary prohibitions $\ldots \ldots \ldots \ldots \ldots \ldots, 734$

3. State of mind elements ............ 736

4. Culpability mental states vs. criminalization mental states ....................

5. Omission rules and the voluntary act requirement .................... 739

6. Justification defenses ............. 740

7. Result elements and causation requirements 742

8. Imputation of culpability mental elements . 743

9. Excuse defenses ................. 744

B. Examples of the Problematic Mixture of Rules of Conduct and Principles of Adjudication .... 745

1. Risk-creation vs. risk-taking .......... 745

2. Justification vs. mistake as to justification . 749

C. Some Classification Challenges ............ 752

1. The consent defense ............... 753

2. De minimis violations $\ldots \ldots \ldots \ldots \ldots \ldots, 754$

D. Summary ....................... 755

III. The Need for Different Drafting Strategies for Rules of Conduct and Principles of Adjudication ....... 758

A. Drafting Strategies ................... 758

B. Drafting Rules of Conduct............. 759

C. Drafting Principles of Adjudication......... 761

IV. Proposals ......................... 765

$\dagger$ Acting Dean and Distinguished Professor of Law, Rutgers University School of Law at Camden. The author wishes to thank Andrew Ashworth, Stephen Morse, Ronald Gainer, and his colleagues who participated in a faculty seminar at Rutgers, for commenting on an early draft of this article. 
I. Rules of Conduct and Principles of Adjudication: The Distinction and Its IMPLications

You are awakened by an unfamiliar sound from the basement garage of your rowhouse. As you sit up in bed the handgun in your hall closet comes to mind; then you remember Earl Miller, a neighbor down the row who shot and killed a night burglar in his garage last year. The prosecutor said Earl had no right to kill the burglar. Earl's attorney claimed that Earl had the right and that even if Earl didn't-although he was sure Earl did-Earl honestly and reasonably believed he had the right. Earl was tried and acquitted. You aren't sure what that means for you. Can you or can't you lawfully shoot a burglar in your basement garage?

You grab your gun from the hall closet and head down to the first floor. The light switch is at the head of the basement stairs. You open the door quietly, flip the switch, and draw back into the dark hall. Something drops to the basement floor, followed by the sound of steps, the shattering of glass, a muffled scream, and silence. On descending the stairs, you find your back window broken and the intruder motionless, blood pouring from a cut in his neck.

You believe you could stop the bleeding by applying pressure but you don't really want to help the man: after all, he had been stealing from you. And on top of that, the gushing blood and mess make you wince. Should you help him? Must you? You aren't sure.

You remember the newspaper story about the motorist who stood and watched another motorist bleed to death after their cars collided. The prosecutor claimed that the motorist could have and should have stopped the bleeding, but he stood and watched ... which is exactly what you are doing now. The motorist's attorney claimed that he had no legal duty to act and, in any case, was dazed from the accident. The man was tried and acquitted. What does that mean for you? If you can, must you help the intruder? Will you be a criminal if you just stand and do nothing? You wish you weren't thinking so clearly. Perhaps it would have been better to have fallen down the stairs and been dazed. Not a good time to be making jokes, you conclude.

The rules of lawful conduct frequently are unclear even to actors who are intelligent, thoughtful, and informed. Can you lawfully shoot the intruding burglar? Does the law require that you aid the helpless burglar? In the situation described above, the actor knows the disposition of a recently litigated case closely analogous to each dilemma confronted, and seeks to use that outcome to 
guide his own conduct; yet he is still unable to discern the applicable legal rules.

Such uncertainty is not uncommon in our current system. Frequently, neither existing statements of the law nor our process of public adjudication effectively communicate the rules that define lawful conduct. My thesis in this article is that current criminal law doctrine does a poor job at one of its most important functions: telling people what they can, must, and must not do, under threat of criminal sanction.

Our condemnation and punishment of criminals, as distinguished from civil violators, rests upon an assumption that a criminal violation entails some consciousness of wrongdoing or at least a gross deviation from a clearly defined standard of conduct. But how can such an assumption be sustained if the demands of the law are unclear? How can we condemn and punish violations of the rules of lawful conduct if the rules are not and cannot reasonably be known by the general public? One also may wonder how effective the criminal law can be in deterring criminal conduct if the law's demands are unclear.

In this article I will show why our legal system's rules of conduct are presently unclear, how the system arrived at its current state, and what can be done to make the rules of conduct clearer. My arguments and conclusions are, in brief, as follows: The criminal law fails to communicate clear rules of conduct because it fails to distinguish this communicative function from that of adjudicating violations of the rules, which requires primarily an assessment of the blameworthiness of the violator. These two functions-announcing public rules of conduct and assessing individual blame in adjudication of a violation-have very different doctrinal foundations. ${ }^{1}$ The rules of conduct function gives the general population ex ante direction as to what they can, must, and must not do. The principles of adjudication function gives decisionmakers (i.e., prosecutors, juries, and judges) guidance in assessing ex post the blameworthiness of an individual's violation of the rules. Section II of this article illustrates the rules of conduct/principles of adjudication distinction by identifying how different aspects of current law effectively serve these functions.

\footnotetext{
1 The distinction is an application of one found in legal philosophy between rules to guide the general public's behavior and rules for decisionmakers. The distinction was recognized in Talmudic law, used by Bentham, and recently reexamined by Dan-Cohen. See Meir Dan-Cohen, Decision Rules and Conduct Rules: On Acoustic Separation in Criminal Law, 97 Harv L Rev 625, 626 n 1 (1984).
} 
The failure to distinguish between these two functions in formulating the criminal law creates two kinds of difficulties. First, the doctrines may be ineffectively formulated and codified for their primary function. For example, rules of conduct need to communicate a legal standard that can be understood, remembered, and applied by the general public. Can one lawfully shoot a basement burglar? Must one help him when he is bleeding and helpless? Unfortunately, rules of conduct are frequently drafted in a form that is more appropriate for a principle of adjudication, entailing broad and open-ended inquiries into a variety of factors that determine blameworthiness. Many people consequently cannot discern the answers to these questions from the applicable rule of conduct. And many people who think they know the answers will be wrong. Conversely, principles of adjudication frequently are drafted in a form that may be appropriate for a rule of conduct but that does not accommodate the complex and multi-faceted analyses that determine an actor's blameworthiness for violating a rule of conduct.

To be effective, the rules of conduct must be simple, based on objective criteria with easily communicable and comprehensible standards. The doctrines embodying the principles of adjudication, on the other hand, must take account of the complex and varied situational factors relevant to an actor's blameworthiness, as well as the capacities and characteristics of the particular actor. The principles also must incorporate or at least mirror the community's expectations of the actor. In other words, they must use subjective criteria and rely upon more individualized, judgmental, and normative standards. Section III of this article describes and discusses errors made in the formulation and drafting of legal rules, and suggests some general drafting strategies.

A second difficulty arising from the criminal law's failure to distinguish between rules of conduct and principles of adjudication is the ambiguity resulting from acquittals and dismissals, and this ambiguity's detrimental effect on the rules of conduct function. Does the acquittal of the neighbor who shot the burglar mean that shooting burglars is lawful, in the sense that it is permitted by the rules of conduct? Or, rather, does the acquittal mean that such killing is not permitted but that the neighbor's mistake on the issue was, under the circumstances, not blameworthy? Similarly, does the acquittal of the motorist who let the accident victim bleed to death mean that there is no legal duty to help; or does it instead mean that, despite his legal duty to help, the motorist, given his particular (perhaps dazed) condition and his particular (perhaps decreased) abilities, could not fairly be blamed for his inaction? 
Instead of restating, reinforcing, and refining society's rules of conduct, acquittals at public trials (as well as dismissals by courts and publicly-reported decisions not to prosecute) frequently serve only to create ambiguity and confusion regarding those rules. Does the failure to condemn and punish follow from the propriety of the actor's conduct, or from the actor's blamelessness for admittedly improper conduct? Only a system that distinguishes a no-violation-of-the-rules-of-conduct acquittal from a blameless-violation acquittal can avoid this ambiguity and resurrect the educational value of our public adjudication system. Section IV sets out a number of proposed procedural reforms designed to implement this and other changes in the criminal law.

\section{Rules of Conduct and Principles of Adjudication in CURRENT Doctrine}

\section{A. The Distinction Applied to Current Doctrine}

What aspects of current criminal law state society's rules of lawful conduct? That is, which of the existing criminal law rules must citizens know in order to keep their conduct lawful? The surprise, for me, in the relatively comprehensive review that follows is the large proportion of criminal law that is not part of the rules of conduct, but that serves some other function, most notably the ex post function of assessing a violator's blameworthiness.

\section{Objective elements of an offense.}

In a typical criminal code, the bulk of the rules of conduct are found in the offense definitions, which are usually set out in a Special Part. The objective elements of an offense seem, at first, to do no more than define the conduct prohibited by that offense (i.e., they describe the rule of conduct), while the mental elements seem to determine whether the actor has satisfied the objective elements under circumstances that we would consider blameworthy (i.e., they describe the relevant principle of adjudication). As shall become apparent, however, such generalizations are inaccurate with respect to both objective elements and mental elements.

The objective elements of offense definitions typically describe prohibited conduct: one may not enter on another's land without license, one may not offer a bribe to a juror, one may not cause injury to another person, etc. The Model Penal Code's offense definitions are constructed from three classes of objective elements: 
conduct, circumstance, and result. ${ }^{2}$ An offense definition generally prohibits conduct under certain circumstances (i.e., without license) or conduct that causes a specified result (i.e., injury to another person).

But the common, "objective" nature of objective elements hides an important distinction: not all objective elements of offense definitions are part of the rules of conduct. Results are objective, like conduct and circumstances, and are quite unlike the subjective mental elements of purpose, knowledge, and recklessness. But result elements are different from other objective elements in that they do not describe the conduct that an actor is prohibited from engaging in. The rules of conduct address themselves to an actor's conduct, not its result, for it is only the actor's conduct that the rules can influence. The rules may purport to prohibit a particular result but in fact all they can do is direct actors not to engage in particular conduct that is certain to bring about--or risks bringing about-that result. A real resulting harm may properly make the violation more serious, but the fortuity of whether the result actually occurs does not alter the existence of a violation; the nature of the conduct that constituted the violation remains unchanged. Thus, result elements of offense definitions properly belong in the principles of adjudication.

\section{Secondary prohibitions.}

The conduct and circumstances elements of specific offense definitions define the primary prohibitions of the criminal law. But the criminal law prohibits not only conduct that violates a primary prohibition, but also conduct toward that end. These secondary prohibitions proscribe assisting, attempting, soliciting, and conspiring to commit prohibited conduct. The secondary prohibitions thus enlarge the primary prohibitions: just as one may not violate a primary prohibition, neither may one assist or attempt or solicit or conspire to commit such violation.

Secondary prohibitions typically are of two sorts: (1) doctrines expanding the primary prohibition by imputing to the actor the

'See Model Penal Code § 1.13(q) (ALI, 1962) (“MPC"). See generally Paul H. Robinson and Jane A. Grall, Element Analysis in Defining Criminal Liability: The Model Penal Code and Beyond, 35 Stan L Rev 681 (1983). The Code does not define the terms "conduct," "circumstance," and "result," but I have suggested definitions elsewhere. Id at 71925. 
conduct of another, as in complicity, ${ }^{3}$ and (2) doctrines expanding the primary prohibition by prohibiting conduct short of the substantive harm or evil, as in the inchoate offenses of attempt, conspiracy, solicitation, and possession. Secondary prohibitions sometimes are contained in general code provisions that incorporate by reference the offense definition containing the primary prohibition, as with general inchoate offenses and complicity provisions. ${ }^{4} \mathrm{Sec}-$ ondary prohibitions also sometimes are contained in specific offenses, such as special codified attempt provisions (i.e., assault with intent to rape, burglary, and possession of burglar's tools).

The function of the elements of the first kind of secondary prohibition-which imputes to the actor another's conduct, as in complicity-reflects a pattern similar to offense definitions. The conduct and circumstance elements of the doctrine constitute the rule of conduct, while the mental elements required by the doctrine serve the function of the adjudicatory principles of blame. An actor charged with complicity in theft, for example, may lack the culpability required for liability; his negligence will be insufficient for liability if the offense requires purpose, knowledge, or recklessness as to ownership by another. Yet all persons are warned that the rules of conduct forbid assisting another to take a third person's property, even though this actor is not to be punished for his violation. ${ }^{5}$

The same analysis applies to other doctrines that impute conduct, such as liability for causing crime by an innocent, the Pinkerton doctrine, and the complicity aspect of the felony-murder

\footnotetext{
3 For a discussion of the imputation of conduct and other objective elements, see Paul H. Robinson, Imputed Criminal Liability, 93 Yale L J 609, 613-15, 617-18 (1984). Doctrines of omission liability, which might be viewed as imputing required conduct, are discussed in text at notes $16-20$.

- See, for example, MPC $\S$ 2.06, 5.01-5.03.

- One could argue that, as with attempt (see text at notes 10-14), some of the mental elements of the complicity doctrine are required to define the prohibition. That is, as with attempt, conduct that normally is lawful can be a violation of the rules of conduct if done with the intention to assist an offense. Thus, the intention to assist another to commit an offense is necessary in some instances to the criminalization of conduct. But the prohibition against assisting or encouraging has objective meaning independent of the intention. An omniscient observer viewing the objective circumstances can determine whether an actor is in fact assisting a violation, and the rules of conduct should announce that such assistance is prohibited. No similar observation and conclusion is possible in the case of attempts, even for an omniscient observer aware of all observable facts. There, the observer frequently must know the actor's intention to know whether his conduct is an attempt to violate a rule of conduct.
} 
rule. ${ }^{6}$ Under a doctrine of imputation, an actor is held liable although he does not satisfy the elements of the offense definition. The conduct and circumstance elements of these doctrines typically define the ways in which the rules of conduct prohibition has been expanded to cover the actor's conduct. The mental elements function to assess the actor's culpability for the violation.

The second kind of secondary prohibition-inchoate conduct-reflects a different pattern, which is discussed below. Let me lay a foundation for this by examining more carefully the function of mental elements.

\section{State of mind elements.}

Typically, an offense's objective conduct and circumstance elements are adequate to describe the prohibition: entering another's land without license, having intercourse with a girl under ten, engaging in conduct that will cause or risks causing the death of another human being, etc. ${ }^{7}$ The state of mind $^{8}$ requirements of an offense-i.e., knowledge of lack of license, negligence as to the girl being under ten, or awareness that one's conduct will cause or risk another's death-are not necessary to describe the conduct that is prohibited. ${ }^{9}$ Even if the actor escapes liability because he does not satisfy the state of mind requirements-i.e., he did not know his entry was unlicensed, he was non-negligent as to the girl being under ten, or he was unaware that his conduct would cause or risk another's death-the actor's conduct nonetheless should be avoided by all persons in the future. In other words, despite the actor's acquittal for lack of culpability, his behavior did violate the rules of conduct.

\footnotetext{
- For illustrations and authorities for each of these doctrines and for other doctrines imputing an objective element, see Robinson, 93 Yale L J at 614-15, 617-18 (cited in note 3).

7 Of course, proof of some objective elements may hinge upon proof of another person's mental state, such as; absence of a victim's consent, see, for example, 11 Del Code Ann $\S \S 767,770(1), 771(1), 772(1) \&(3), 773(1), 774(1) \&(2), 775(1) \&(2)$ (1974) (all including absence of "consent" as an element of sex offenses); the victim's fear, see, for example, Tex Penal Code Ann $\$ 29.02(a)$ (2) (Vernon 1974) (defining robbery as placing another in "fear" of bodily injury or death during the course of a theft); or the victim's false impression, see, for example, $18 \mathrm{~Pa}$ Cons Stat Ann $\S 3922$ (a)(1) (Purdon 1983) (defining theft by deception to require creation or reinforcement of a "false impression").

'I include negligence within the term "state of mind" even though it is really the culpable absence of a state of mind: that is, culpable unawareness of a risk. I refer here to the mental risk-taking form of negligence and recklessness, not the real world risk-creation form. See text at notes $38-44$.

- Some writers disagree. "[U]nder our present law ... mens rea is crucial to the description of the behaviour we want to prevent." Sanford H. Kadish, The Decline of Innocence, 26 Camb L J 273, 286 (1968).
} 
As with our analysis of objective elements, we initially may be attracted to a generalization that all mental elements are part of the principles for adjudicating blame. But like objective elements, the state of mind requirements of current doctrine include both rules of conduct and principles of adjudication. As an example of a state of mind requirement that is necessary to define the conduct prohibited, consider the general attempt offense. The conduct and circumstance elements of the offense provide some statement of the rules of conduct prohibition, but standing alone these objective elements do not fully define the prohibited conduct. The requirement of conduct that constitutes a "substantial step" toward commission of an offense, common in modern attempt definitions, is inadequate in itself to define the prohibited conduct. ${ }^{10}$ Some conduct may constitute a substantial step as a purely objective matter, but in fact be entirely innocent and acceptable conduct that is not prohibited. Such conduct violates the rules of conduct only when accompanied by an intention to violate the substantive rules. ${ }^{11}$ Lighting one's pipe is not a violation of the rules of conduct, unless it is a step in a plan to ignite a neighbor's haystack. Giving a young girl a ride is not a violation of the rules of conduct, unless it is done with the intention of sexually assaulting her. Thus, to describe the minimum requirements of prohibited conduct, the rules of conduct for attempts must include a state of mind requirement-the intention to engage in conduct that would constitute a rule violation. ${ }^{12}$

\footnotetext{
10 The prohibition against attempting to violate a rule of conduct includes, in modern statutes, even those instances where the only possibility of a successful violation is in the actor's mind. It seems likely that most people would deem such "impossible attempts" unacceptable conduct. See, for example, Ira P. Robbins, Attempting the Impossible: The Emerging Consensus, 23 Harv J Leg 377, 419-22 (1986); Paul H. Robinson, 1 Criminal Law Defenses $\S 85$ (West, 1984). Existing doctrine prohibits and punishes such imagined violations. See, for example, MPC $\$ 5.01$ (1)(a) comment 3 (punishing impossible attempts by providing that the defendant's conduct be judged under the "circumstances . . . as he believes them to be"); id, comment 3(b)-(c) (describing policy considerations and the Model Penal Code's position). This form of attempt liability relies most heavily on an actor's subjertive state of mind; even the risk of a successful violation of the rules of conduct's substantive prohibitions exists only in the actor's mind.

${ }_{11}$ Thus MPC $\$ 5.01(1)(c)$ only prohibits a "substantial step in a course of conduct planned to culminate in [the] commission of the crime" (emphasis added).

12 A similar intention requirement exists in codified attempt offenses such as assault with intent to rape or burglary (which requires an intention to commit a felony within). There is some confusion over the meaning of the intent requirement in attempts, as embodied in the common law view that "attempt is a specific intent offense." I argue that the necessary intent should be merely the actor's intention to engage in the conduct constituting the substantive offense. See Paul H. Robinson, Fundamentals of Criminal Law: Teacher's Manual 72-73 (Little, Brown, 1988). Others argue that the actor must intend all elements of
} 
The same analysis might be made for conspiracy and solicitation; under this approach, conduct would violate the prohibition against conspiracy or solicitation only if accompanied by an intention to conspire with or solicit another to commit a substantive violation of the rules of conduct. On the other hand, conspiracy and solicitation might be distinguishable from attempt. One could argue that the rules of conduct ought to prohibit agreeing with or soliciting another to violate the rules of conduct, even if the actor does not intend that he or the other person violate the rules. Any agreement or apparent agreement to commit an offense and any solicitation of another to commit an offense might be seen as harmful conduct. The harmfulness of the conduct does not always depend upon the actor's subjective state of mind. Therefore, the rules of conduct might appropriately prohibit all agreements and solicitations to commit an offense, no matter whether intentional or inadvertent. That is, the rules might require one to avoid conduct that even accidentally gives the appearance of such an agreement or solicitation. Recall Henry II's rhetorical question, "Who will free me from this turbulent priest?" which was mistaken as a directive to kill Thomas Becket. ${ }^{13}$ One's lack of intent may suggest a lack of blameworthiness, but society may nonetheless seek to discourage even inadvertent agreements and solicitations. ${ }^{14}$ There is no analogously harmful "unintended attempt."

the offense, including circumstance and result elements. See, for example, People v Trinkle, 68 ill 2d 198, 369 NE2d 888, 890-91 (1977).

13 For a modern analogy, see Ben A. Franklin, Teamster Defendant Accused of Role in a Murder, NY Times A28 (Feb 10, 1983).

${ }_{14}$ Many statutes' reliance upon subjective criteria such as mental elements in defining the prohibition against attempt limits their effectiveness in describing and communicating the prohibited conduct. See the discussion of superiority of objective criteria for formulating the rules of conduct in Section III of this article. This may explain in part why attempt liability, especially liability for impossible attempts, generates such controversy, and why some common law formulations of attempt (for example, the res ipsa loquitur test) require that the actor's intention to commit the offense be manifested in his conduct, thus making the criteria more like the objective criteria found in other parts of the rules of conduct. The objective elements of these attempt formulations might themselves be sufficient to describe the conduct constituting an attempt, and thus might provide a rule of conduct that does not require reference to the actor's state of mind. The difficulties with the subjective aspect of the rules of conduct also may explain why some modern attempt formulations and proposals would require more objective evidence of the actor's intention to commit an offense. Model Penal Code $\S 5.01(2)$ 's evidentiary requirement that the "substantial step" conduct be "strongly corroborative of the actor's criminal purpose" resembles some of the common law formulations. The same concerns may explain the host of offenses that essentially codify, and thereby objectify, attempt liability, such as offenses that criminalize the possession of instruments of crime or the possession of drugs. On the other hand, one might argue that there is little reason to insist that the rules of conduct tell an actor who intends to violate 
4. Culpability mental states vs. criminalization mental states.

The above analysis of attempt offenses suggests that there are two distinct categories of mental elements: culpability mental elements, which function as part of the principles of adjudication, and criminalization mental elements, which are a necessary component of the rules of conduct. Criminalization mental elements typically appear in secondary prohibitions and require an intention to violate a primary prohibition, such as the requirement in attempt that the actor intend to engage in conduct that constitutes a substantive offense.

An offense containing criminalization mental elements will often contain culpability mental elements as well. In attempted assault, for example, the intention to engage in the conduct constituting the assault is a criminalization mental element; as noted above, it is necessary to a description of the prohibited conduct. The requirement in the same offense that the actor manifest at least recklessness as to the victim being a person ${ }^{16}$ is a culpability mental element. That is, the rule of conduct is complete even without this requirement; actors are warned not to attempt to assault persons even though this actor will not be punished for his assault because he was faultless or only negligent as to the victim being a person (e.g., he attempted to abort what he believed to be an inviable fetus, or he set a hunting trap for what he thought was a dog stealing his chickens).

5. Omission rules and the voluntary act requirement.

Another area where current doctrine mixes rules of conduct and principles of adjudication is that of omission liability. The duty requirement in omission liability provisions serves as a rule of conduct; the various legal duties to act describe what affirmative actions the rules of conduct require actors to take. ${ }^{16}$ The capacity

the rules of conduct precisely when his conduct has reached the point of being criminal. Vagueness in this aspect of the rules may be tolerable if not desirable.

${ }^{16}$ Under MPC § 211.1, for example, the assault must be upon another human being. Model Penal Code $\$ 2.02(1)$ requires proof of culpability "with respect to each material element of the offense."

10 Under present law, a duty to act arises in two ways. First, a special offense defined in terms of an omission may create the duty and, in the same provision, punish the failure to act. See, for example, Minn Stat Ann $\S 604.05$ (West Cum Supp 1987) (persons at the scene of an emergency must give reasonable assistance to a victim who has suffered grave physical harm); and RI Gen Laws \& 11-56-1 (Cum Supp 1987). Compare Wis Stat Ann § 940.34 (West Cum Supp 1987-88) (person who knows that a crime is being committed and that its victim is exposed to bodily harm must provide or summon assistance; private detectives and 
requirement in omission provisions serves as a principle of adjudication; it bars liability for violation of a legal duty when the actor cannot be blamed for her failure to perform. ${ }^{17}$

Like the capacity requirement in omission offenses, the voluntary act requirement performs the principle of adjudication function in commission cases. ${ }^{18}$ While the voluntary act requirement is sometimes thought of as a required objective element (actus reus) of every offense, ${ }^{19}$ it does nothing to define the rules of conduct. Rather, it exculpates an actor whose violation of the rules is blameless because her conduct was involuntary. ${ }^{20}$

\section{Justification defenses.}

The various rules of conduct described so far contribute to what may be called the doctrines of criminalization. They tell per-

security guards must report crime if there is a reasonable basis for a belief that a crime has been committed). If no special offense for omission exists, an actor nonetheless may be criminally liable under an offense that on its face prohibits conduct or conduct causing a prohibited result, if the prohibited conduct or result occurs because of the actor's failure to perform a duty. See, for example, Commonwealth $v$ Welansky, 316 Mass 383, 55 NE2d 902, 909 (1944) (bar owner violated duty to prevent and take measures to handle fires; the court reasoned that while reckless conduct usually requires an affirmative act, where there is a duty of care reckless conduct may consist of intentional failure to perform it). The principle permitting substitution of a failure to perform a legal duty for the conduct requirement of an offense has been incorporated into many modern criminal codes. See, for example, statutes cited in Robinson, 1 Criminal Law Defenses $\$ 86$ (a) at $440 \mathrm{n} 2$ (cited in note 10). A general duty to aid exists for actors in particular relationships to the victim-for example, where the actor has a family or contractual relationship with the person who is endangered. See, for example, Jones $v$ United States, 308 F2d 307, 310 (DC Cir 1962); Robinson, 1 Criminal Law Defenses $\$ 86(c)$ (2) at 445-48 (describing the sources of a duty to act).

${ }^{17}$ See, for example, MPC \& 2.01(1); authorities cited in Robinson, 1 Criminal Law Defenses $\$ 87$ at 449 (cited in note 10). The general excuse defenses-such as duress, insanity, and involuntary intoxication-also will be available to hold an actor blameless for his violation of the rules of conduct by omission to act.

${ }_{18}$ MPC $\$ 2.01(2)(d)$ (an actor's conduct is involuntary if the conduct constituting the violation "is not a product of the effort or determination of the actor"). While the rules of conduct prohibit striking another person, doing so during a seizure in an elevator may not violate our normative expectations for the epileptic. Of course, if the epileptic knew or should have known of her condition and should have taken steps to prevent the blow, we might feel differently about the violation. See generally Paul H. Robinson, Causing the Conditions of One's Own Defense: A Study in the Limits of Theory in Criminal Law Doctrine, 71 Va L Rev 1, 30-36 (1985).

19 See, for example, Rollin M. Perkins, Criminal Law 605 (Foundation, 3d ed 1982).

${ }^{20}$ It is not entirely clear whether the voluntariness requirement and the analogous capacity requirement for omissions create a presumption of blameworthiness on the part of the actor who has satisfied them, and thus are doctrines of culpability, or whether the defenses of involuntariness and incapacity rebut a presumption of culpability, and thus are doctrines of excuse. See text following note 31 . I tend toward the latter view because, like the general excuses, involuntariness and incapacity are abnormalities, not attributes of an ordinary person, such as the culpable mental states of purpose, knowledge, and recklessness. 
sons what they cannot (or must) do. A second part of the rules of conduct tells persons when they may legally engage in conduct that violates a doctrine of criminalization. The doctrines of justification, as they may be called, tell persons that they may engage in the described conduct even though such conduct would be a violation of the rules of conduct absent the justification. ${ }^{21}$ The rules of conduct do not require an actor to do everything that is justified (as, for example, in the omissions context), but the actor remains within the rules of conduct if his violation is justified. The common justifications, usually available as defenses, include the lesser evils doctrine; ${ }^{22}$ the defensive force doctrines of self-defense, defense of others, defense of property, and defense of habitation; and the public authority doctrines of law enforcement authority, authority to maintain order and safety, parental authority, benevolent custodial authority, medical authority, authority to prevent a suicide, judicial authority, military authority, and general public authority. ${ }^{23}$

That the justification portion of the rules of conduct typically is formulated as a series of defenses is appropriate. A violation of a doctrine of criminalization may be said to create a presumption that the rules of conduct have been violated. The doctrines of justification serve to rebut that presumption where appropriate by recognizing that the circumstances of the violation make the conduct acceptable. Note that under this conceptualization, the doctrines of justification are not doctrines of "exculpation," as they

21 The phrase "doctrines of justification" refers primarily to the general justification defenses. See, for example, MPC Art 3. But the phrase and the underlying concept also include doctrines of similar effect that are found in a variety of other places. For example, recklessness and negligence are defined to exclude "justified" risks. See MPC $\S 2.02(2)(c),(d)$. On the role of justification defenses in providing ex ante conduct rules, see George P. Fletcher, The Right and the Reasonable, 98 Harv L Rev 949, 976 (1985).

${ }_{22}$ As a general principle, conduct that violates a prohibition will be justified if it avoids a greater harm than the prohibition itself. The lesser evils defense explicitly provides for such a balancing. See, for example, MPC \$ 3.02(a). Other special rules that limit the amount of force authorized according to the nature of the harm threatened reflect the same principle. See generally Robinson, 2 Criminal Law Defenses $\S \S 121(\mathrm{a})(2)(\mathrm{B}), 124(\mathrm{~d}),(\mathrm{g}), 131(\mathrm{~d})$, $141(\mathrm{e})$ at $5,50-54,60-68,81-88,118-20$ (cited in note 10) (describing the statement of the proportionality requirement in the lesser evils, defensive force, and public authority justifications). But see Kent Greenawalt, The Perplexing Borders of Justification and Excuse, 84 Colum L Rev 1897, $1904 \mathrm{n} 22$ (1984) (arguing that this is "serious oversimplication" of the nature of justifications).

${ }^{23}$ For illustrations and authorities for each of these defenses and for a discussion of the relations among them, see Paul H. Robinson, Criminal Law Defenses: A Systematic Analysis, 82 Colum L Rev 199, 213-16 (1982). 
are commonly described;" they do not "clear from alleged fault or guilt."25 Violation of a doctrine of criminalization does not create a presumption of fault or guilt-such a presumption comes only after application of the adjudicatory principles of blame-so there is no fault or guilt yet established from which the actor can be "exculpated" by a doctrine of justification.

This completes my survey of current doctrines embodying the rules of conduct. Although we have briefly encountered some principles of adjudication in the preceding materials, the remainder of this section looks more closely at the current doctrines that function as principles of adjudication. As noted previously, a large portion of the principles of adjudication is contained in the culpability (as opposed to the criminalization) mental elements of offense definitions. But other elements of current law-such as result and causation requirements-also perform the principles of adjudication function.

\section{Result elements and causation requirements.}

Result elements of offense definitions-requiring the actual occurrence of the undesirable consequence-serve the ex post function of assessing the degree of an actor's blameworthiness. Traditionally, greater blame is assigned to an actor who actually causes a death, for example, than to an actor who engages in the identical conduct with an identical state of mind but who, luckily, does not in fact cause a death. ${ }^{26}$ The propriety of this aspect of the doctrine has been debated. ${ }^{27}$ The point here is that the debate over whether there is greater blameworthiness when the harm comes about is a disagreement over principles of adjudication. So far as the rules of conduct are concerned, there is general agreement that the rules ought to prohibit conduct that creates a risk of certain undesirable consequences, regardless of the fruition of those consequences.

24 See, for example, George P. Fletcher, Rethinking Criminal Law 759-62 (Little, Brown, 1978); and H. L. A. Hart, Punishment and Responsibility: Essays in the Philosophy of Law 13-14 (Oxford, 1968). Fletcher describes a distinction in German criminal law theory-between what he calls "wrongdoing" and "subject attribution"- that is similar in some respects. See Fletcher, Rethinking Criminal Law at 455.

${ }^{25}$ Webster's Ninth New Collegiate Dictionary 433 (Merriam-Webster, 1986).

${ }^{36}$ For a list of statutes providing reduced liability for attempts, see Paul H. Robinson, Fundamentals of Criminal Law 488-89 (Little, Brown, 1988).

${ }^{27}$ For an analysis of the impropriety of taking account of resulting harm, see Stephen J. Schulhofer, Harm and Punishment: A Critique of Emphasis on the Results of Conduct in the Criminal Law, $122 \mathrm{U}$ Pa L Rev 1497 (1974). 
The same analysis suggests that a causation requirement in offense definitions also presents a principles of adjudication issue. While, again, a causation requirement may resemble a rule of conduct's objective criteria -it is, after all, a required relation between two objective elements, the actor's conduct and a prohibited result-the causation requirement typically adds nothing to the definition of the prohibited conduct.

Because result elements and causation requirements are not necessary to defining the conduct prohibited by the criminal law, it is not surprising that the presence of some form of liability rarely depends upon them. If a prohibited result does not occur or if a required causal connection is not established, the actor typically is liable for a lesser offense, such as attempt. ${ }^{28}$ This is consistent with the conceptualization proposed here that the rules of conduct have been violated in such cases even in the absence of the prohibited result or causal connection.

\section{Imputation of culpability mental elements.}

Aside from the important exception of criminalization mental elements noted previously, most mental elements are culpability mental elements, which function as principles of adjudication. The doctrines that impute culpability mental elements similarly function as principles of adjudication, since they neither expand nor refine the prohibitions of the rules of conduct. The doctrine of voluntary intoxication, for example, imputes to an actor a required awareness of a risk that he may not in fact possess. ${ }^{29}$ Such a doctrine, by imputing a culpability mental element, expands the instances in which an actor's violation will be held blameworthy. That is, culpability may arise either from consciously risking that one's conduct is of a nature that violates a rule of conduct (e.g., having intercourse with a girl while aware that she may be underage) or consciously risking becoming intoxicated (and, therefore, being unaware of a risk that the girl is underage).$^{30}$ Other doctrines imputing culpability mental elements include transferred intent,

\footnotetext{
28 This is always true for intentional offenses in jurisdictions that have general attempt statutes, as nearly two-thirds of the states do. See Robinson, 1 Criminal Law Defenses

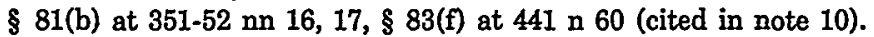

29 See, for example, MPC $\$ 2.08(2)$. For a discussion of other doctrines that impute a required culpability, see Robinson, 93 Yale $L J$ at 615-18 (cited in note 3).

so Because I question the propriety of equating the second culpability with the first, I have argued elsewhere that many voluntary intoxication cases could be resolved by imposing liability based upon the actor's conduct and actual culpability as to the offense elements at the time of his intoxication. See Robinson, $71 \mathrm{~V} a \mathrm{~L}$ Rev at 35-36 (cited in note 18).
} 
substituted mental elements, presumptions imputing culpability elements, the natural and probable consequence rule in complicity, and various forms of vicarious liability. ${ }^{31}$

\section{Excuse defenses.}

The principles of adjudication reflect a structure of presumption and rebuttal similar to the criminalization and justification doctrines of the rules of conduct. Most of the doctrines discussed above that perform the principles of adjudication function-for example, the culpability mental elements of offense definitions and of doctrines imputing objective elements; and the doctrines imputing culpability mental elements-establish culpability, or at least a rebuttable presumption of it. They may be called the doctrines of culpability. The presumption of blame created by these doctrines can be rebutted by what may be called the doctrines of excuse. The most common doctrines of excuse are general excuse defenses.

If the actor satisfies the conditions of a general excuse defense at the time of the violation, his apparently culpable violation of the rules of conduct will be held blameless. When, for example, as a result of mental disease or defect or involuntary intoxication, a person "lacks substantial capacity either to appreciate the criminality [wrongfulness] of his conduct or to conform his conduct to the requirements of law," ${ }^{32}$ society lowers its normative expectations of the person; thus we may hold blameless his violation of the rules of conduct. That the violator is thirteen years old also affects our assessment of blameworthiness and is taken into account under an immaturity excuse..$^{33}$ Similarly, when an actor violates the rules of conduct because he was coerced to do so, the duress excuse exculpates him. ${ }^{34}$ In addition to the traditional disability excuses of insanity, subnormality, immaturity, and duress, current doctrine sometimes recognizes general excuses in special circumstances of mistake: when an actor relies upon an official misstatement of the law; when an actor could not have been expected to know the law because it was not made reasonably available; or

${ }^{31}$ For illustrations and authorities for each of these doctrines, see Robinson, 93 Yale $L$ $J$ at 615-18 (cited in note 3).

${ }_{32}$ MPC $\$ \S 4.01(1), 2.08(4)$. Other formulations of these defenses are common. See text and authorities in Robinson, 2 Criminal Law Defenses § 173(a) at 280-83 (insanity formulations), \& 176(a) at 337-39 (general intoxication-excuse formulations) (cited in note 10).

${ }^{3}$ See, for example, MPC $\$ 4.10$ (immaturity) and authorities cited in Robinson, 2 Criminal Law Defenses $\$ 175$ at 321 (cited in note 10).

st See, for example, MPC $\$ 2.09$ and authorities cited in Robinson, 2 Criminal Law Defenses $\S 177$ at 347 (cited in note 10). 
when the actor was (reasonably) mistaken in his belief that his conduct was justified. ${ }^{35}$

Excusing conduct because of the actor's mistaken belief that his conduct is justified merits further discussion. Some writers argue that such a mistaken justification ought to be described as justified conduct. ${ }^{36}$ That is, they would define justification defenses subjectively; an actor would be justified if he (reasonably) believed that his conduct was justified. As the discussion of this point in the next section concludes, however, such a subjective formulation of justification defenses hides the important distinction between true (objective) justification, which serves the rules of conduct function of advising people what they are and are not permitted to do, and mistaken (subjective) justification, which serves the principles of adjudication function of excusing actors who have acted under a mistaken belief that their conduct is justified. ${ }^{37}$

B. Examples of the Problematic Mixture of Rules of Conduct and Principles of Adjudication

Given the extent to which current doctrine generally fails to recognize the distinction between rules of conduct and principles of adjudication, it is no surprise that, as has been noted, the two functions sometimes are combined in a single doctrine. In certain instances, the mixture can become so complete as to be problematic.

1. Risk-creation vs. risk-taking.

Current doctrine does not distinguish between creating a risk of causing a prohibited result (i.e., real world risk-creation) and taking a risk that one's conduct is prohibited due to circumstances that may exist (i.e., mental risk-taking). The former issue-real world risk-creation-presents a rules of conduct issue: what is the kind and degree of risk of harm that an actor is prohibited from

ss See, for example, MPC § 2.04(3)(a) and authorities cited in Robinson, 2 Criminal Law Defenses $\$ \S 182,183$ at 381, 386 (cited in note 10). Other general excuses recognized include a general reasonable mistake of law defense, for example, NJ Stat Ann \& 2C: 24(c)(3) (West 1982); and a defense for conduct under hypnosis, for example, MPC $\S 2.01(2)$ (c). For a discussion of each of the excuse defenses noted in the text and their interpretation, see Robinson, 82 Colum $L$ Rev at 213-16 (cited in note 23).

st See Wayne R. LaFave and Austin N. Scott, Jr., Criminal Law $\$ 5.7$ at 454, 457 (West, 2d ed 1986); and Greenawalt, 84 Colum L Rev at 1919-20 (cited in note 22).

${ }^{37}$ See text at notes $52-57$. 
creating? ${ }^{38}$ The latter issue-mental risk-taking-presents a culpability issue: when is an actor to be held blameworthy for "taking a risk" that his conduct violates the rules of conduct? The distinction is between creating a risk of causing a harm and taking a risk of violating a rule.

"Recklessness" offenses are an example of an area of current doctrine that confuses the two types of risk. One form of recklessness is the intentional creation of a risk of harm. For example, intentionally creating a risk of death appears to be punished as reckless homicide where the death occurs and as intentional endangerment where it does not. ${ }^{39}$ This punishes real world riskcreation, for which the rules of conduct must define the extent and nature of the prohibited risks. A different form of recklessness is consciously disregarding a risk that one's behavior constitutes a rules of conduct violation. An actor shoots at a shadow behind a shade, unsure whether it is a welcome neighbor or his unwelcome dog. He is certain to achieve his goal of causing death; his recklessness goes to whether the death will be one that is prohibited by the rules of conduct-the death of a human being. This mental risktaking is, like real world risk-creation, punished as reckless homicide, but only if the shadow turns out to be that of a human. Otherwise, there is no liability. The recklessness required by offenses without result elements generally is of the mental risk-taking, not real world risk-creation, sort. Statutory rape, for example, punishes mental risk-taking as to a sexual partner's age. ${ }^{40}$ If the partner is

ss There is no comparable risk-creation for violations that do not involve causing a prohibited result. Where the prohibition is defined only in terms of conduct in certain circumstances, the circumstance either exists or it does not. One does not create a risk of a circumstance; one can only take a risk that a circumstance exists. That is, one acts in disregard (or ignorance) of the risk that the circumstance exists. Such mental risk-taking is an issue of culpability.

so For example, an actor may dump a hazardous chemical in an abandoned mine shaft knowing or intending that he thereby creates a risk that the chemical will leak and cause death. The risk is created by the actor's conduct of dumping. Such intentional risk-creation is punished under the Model Penal Code's endangerment offense, \$ 211.2. It is punished no more severely than recklessly creating the same risk. Section 211.2 does not increase the grade of the offense if a culpability greater than the required recklessness is proven. Riskcreation also is punished under offenses that prohibit engaging in specified conduct. See, for example, NJ Stat Ann § 2C:12-1(b)(4) (West Cum Supp 1987-88) (offense to knowingly point a firearm in the direction of another); compare MPC \& 211.2 (pointing a firearm at another creates a rebuttable presumption of the recklessness and danger required for reckless endangerment).

to Many jurisdictions punish not only such conscious mental risk-taking but also an actor's failure to be sufficiently aware of a risk that his conduct might be a violation-i.e., negligence as to a sexual partner's age. Under the Model Penal Code, for example, an actor is liable if he is negligent as to his partner being less than sixteen years old (and the actor is 
underage, the rules of conduct have been violated; if the partner is not underage, there is no violation..$^{41}$ If it turns out that there is a violation, the principles of adjudication must then determine whether the actor is blameworthy for acting despite his awareness of a risk that his conduct was prohibited. ${ }^{42}$

Section IV of this article describes the difficulties and errors that come from drafting rules of conduct in the form appropriate for principles of adjudication and vice versa. The failure to distinguish the two forms of recklessness inevitably leads to such errors. The failure also raises questions about the substantive doctrine. Should the person who intentionally creates a risk of death of a human being (by dumping toxic waste where it might leak into a water supply) be treated the same as the person who engages in conduct certain to cause the death of what he mentally risks is a human being (by shooting point blank at the shadow behind the shade)? Further, if reckless homicide (manslaughter) statutes ${ }^{43}$ are intended to punish either kind of recklessness, are they also intended to punish both kinds together? Is it reckless homicide that one acted in conscious disregard of a substantial risk that one's conduct created a substantial risk of causing death (mental risktaking as to real world risk-creation) ${ }^{44}$ Should this person be subject to the same liability as the person who intends to cause such a risk, and the person who mentally risks certain death? All three may be convicted of the same offense, reckless homicide, but one might argue that one or more ought to have different degrees of liability.

at least 4 years older than his partner). MPC § 213.3(1)(a). Model Penal Code § 213.6(1) provides that only a "reasonable" belief-in other words, non-negligent belief, per $\$ 1.13(16)-$ is a defense. This, of course, also is a culpability issue, not a real world riskcreation issue.

11 Unless, of course, the jurisdiction imposes liability for impossible attempts. For a discussion of the special subjective nature of the attempt rule of conduct, see text at notes 10-14.

42 More accurately, liability for mental risk-taking arises from acting despite an awareness of a risk of the circumstances that in fact make one's conduct prohibited; an actor need not be aware of a risk that his conduct is prohibited. As Model Penal Code $\S 2.02(9)$ illustrates, knowledge of criminality is not normally required for liability.

is A person is guilty of manslaughter if he "recklessly causes the death of another human being." MPC $\S \S 210.1(1), 210.3(1)(a)$.

4 Some offenses more clearly are intended to punish both kinds of recklessness, even together. Reckless endangerment and risking catastrophe, for example, impose liability on an actor who engages in conduct creating a risk of harm while aware that his conduct is creating that risk. See, for example, MPC $\$ \S 211.1,220.2(2)$. Creating the risk of harm violates the rules of conduct; the actor's disregarding his awareness of a risk that his conduct is prohibited makes him culpable for the violation. 
Another example of current confusion in the area of criminal risk is the use of overlapping rules of conduct. Because current doctrine does not distinguish rules of conduct from principles of adjudication, it commonly uses two offenses to prohibit the same conduct, offenses that are distinguishable only by the presence of resulting harm (a factor relating to the principles of adjudication). For example, as noted above, reckless homicide and intentional endangerment each prohibit the same conduct: creating a risk of death. If offense definitions are taken by the public as the rules of conduct, the use of two separate offenses may suggest that two different kinds of conduct are prohibited, which is not true.

The confusion is heightened where the two overlapping offenses use different standards to define the illegal conduct. For example, the Model Penal Code punishes only the creation of a "substantial risk"45 when the risk comes to fruition, but where it happily does not come to fruition, the Code does not specify the prohibited degree of risk. ${ }^{46}$ Presumably it could be less than a substantial risk. If the goal is to establish rules of conduct to shape individual behavior, it seems inappropriate to use a standard that varies depending on the occurrence of a result, a subsequent event over which the actor has no control. At the time of acting, the actor cannot know whether the harm will actually occur. Therefore, an actor cannot know which of the two overlapping prohibitions he is violating. The different standards (and different threatened sanctions) send a confusing message: if you take a risk less than a substantial risk, you will be liable only for the risk-creation, even if the harm comes about; but if you take a substantial risk, you will be subject to greater liability if the harm comes about. A more rational approach would define different offenses and attach different degrees of liability depending on the degree of risk created.

This unsystematic definition of prohibitions also means that conduct creating a risk frequently will be prohibited and punished only if the harm comes about. For example, an actor will be liable (under a subsection of the assault offense) for creating a risk of bodily injury if the injury results, but he will not be liable for creating the same risk of injury if he is lucky and the injury never

\footnotetext{
${ }_{45}$ MPC § 2.02(2)(c),(d). $\S 211.2$.

to See, for example, the requirement of simply creating a "danger" of death in MPC
} 
occurs. ${ }^{47}$ Writers may disagree as to whether, all other things being equal, a resulting harm should increase liability, ${ }^{48}$ but there seems little reason to think that a resulting harm should be a minimum requirement for liability. ${ }^{49} \mathrm{~A}$ rational system would establish a rule of conduct that prohibits the creation of a risk of harm of a defined seriousness (or create a series of offenses defined by the magnitude of the risks created). Then, if desired, the system could impose a greater punishment upon a violation where the result actually occurs. Current doctrine anomalously makes the prohibition of a risk depend upon whether the harm actually comes about, a fact that the actor cannot know at the time he creates the risk.

2. Justification vs. mistake as to justification.

Another illustration of the problematic mixture of rules of conduct and principles of adjudication is found in the common practice of combining justification and mistaken justification in a single defense. Conduct that is actually, objectively justified is consistent with the rules of conduct. Such conduct is to be publicly approved and encouraged (or at least tolerated) under similar circumstances in the future. Conduct that is not actually, objectively justified violates the rules of conduct and should be avoided by others under similar circumstances in the future, although the violator at hand may be excused if his reasonable mistake as to the justification of his conduct makes him blameless. Thus, a defense

47 If the injury occurs, liability will be imposed under MPC $\S 211.1$ (1)(a) (assault). The offense of reckless endangerment only prohibits placing another person in danger of "death or serious bodily injury." MPC § 211.2.

to Some writers would object to any differential in liability based upon the presence or absence of a resulting harm. See, for example, Schulhofer, $122 \mathrm{U} \mathrm{Pa} \mathrm{L} \mathrm{Rev} 1497$ (cited in note 27). But most jurisdictions distinguish liability for the completed offense from a mere attempt. See the authorities collected in Robinson, Fundamentals of Criminal Law at 488. 89 (cited in note 26). See also John H. Mansfield, Hart and Honore, Causation in the Law-A Comment, 17 Vand L Rev 487, 494-95 (1964) (claiming strong intuitive support for a distinction based upon resulting harm).

10 My article, $A$ Theory of Justification: Societal Harm as a Prerequisite for Criminal Liability, 23 UCLA L Rev 266 (1975), has been misinterpreted as a call for a physical harm prerequisite to criminal liability. See, for example, Arnold H. Loewy, Culpability, Dangerousness, and Harm: Balancing the Factors on Which Our Criminal Law is Predicated, 66 NC L Rev 283, 288 (1988) (treating the concept of "harm" used by Robinson as if it related to the harmful physical consequences found in offenses such as homicide). But as my definition of the term "societal harm" makes clear, it includes not only physical but also intangible harm-damage, injury, detriment, and loss of any kind to tangible or intangible interests. Robinson, 23 UCLA L Rev at 267 n 7. For a supporting view, see also Jerome H. Hall, General Principles of Criminal Law 214 (Bobbs-Merrill, 2d ed 1960). 
for mistaken justification serves as a principle of adjudication, not a rule of conduct.

By treating mistaken conduct as "justified," current doctrine creates an ambiguity that risks distorting the true rules of conduct. An acquittal described as justified, but actually based on a mistake as to a justification, sends an unclear message of the rule of conduct: Do the rules permit what the actor actually did or just what he thought he was doing, or both? Giving the same "justification" defense to both the objectively justified actor and the mistaken actor leaves the ambiguity dangerously unresolved in every case. A case of mistaken justification might be misinterpreted as a case of true justification, thereby approving conduct that ought to be prohibited. ${ }^{\text {so }}$ Meanwhile, an actual justification-involving desirable conduct-might be misinterpreted by the public (and decisionmakers) as a mistaken justification involving undesirable conduct, thereby distorting the rules to discourage desirable conduct. ${ }^{51}$

This difficulty occurs in jurisdictions, such as those adopting the Model Penal Code, that label conduct under a mistaken justification "justified" conduct. ${ }^{52}$ The difficulty can be avoided by adopting an objective theory of justification and a separate excuse for the mistaken actor, for this properly distinguishes the two cases and permits a clear communication of the rules of conduct. Thus I have argued elsewhere that the doctrines of justification should be formulated in an objective rather than subjective form: that is, based upon the objective circumstances and not upon the actor's state of mind. ${ }^{53} \mathrm{I}$ continue to believe that subjective justifications

so It is for fear of this mistake that many appropriate reasonable mistakes as to justification are denied excuse. See note 87 , discussing such compensating distortions in fairness doctrines.

${ }^{51}$ Nor is there an opportunity to determine, in a given case, which message is meant to be conveyed by the acquittal-no violation or a blameless violation. Under the present system, no one other than the individual juror can tell whether the verdict is intended to mean that the actor's conduct was not a violation or was a non-blameworthy violation of the rules. Indeed, the jury instructions would not call for deliberation on the issue; and thus there may well be no single group view developed among the jurors. One juror may vote for acquittal because she judges there to be no violation of the rules of conduct; another may vote for acquittal because he finds a violation but judges it blameless. In other words, the system does not require a determination of whether the conduct is a violation, and thus there may be no message to convey at all.

B2 See authorities cited at Robinson, 2 Criminal Law Defenses $\S 184(\mathrm{~b})(1)$ at 399.402 (cited in note 10).

5s Robinson, 23 UCLA L Rev 266 (cited in note 49); Robinson, 2 Criminal Law Defenses $\S 122$ at 12 (cited in note 10). I also continue to support only attempt liability for the unknowingly justified actor and only in those jurisdictions that punish legally impossible attempts. Robinson, 23 UCLA L Rev at 291; Robinson, 2 Criminal Law Defenses at $\S 122(d)$. Such liability for the unknowingly justified actor does not require the subjectivica- 
cannot provide the unambiguous and invariant rules needed to guide the conduct of all persons; ${ }^{54}$ only objective justifications can perform this function.

Many codes and some writers insist on defining justifications subjectively-i.e., they argue that one ought to be justified if one (reasonably) believes that one's conduct is justified. ${ }^{55}$ According to this argument, the actor has behaved properly; to convict him is to improperly disapprove of his conduct as he saw it. One writer gives the example of the Young case, in which the actor bravely intervened to help defend a youth being beaten by two men, only to be charged with criminal assault for interfering with an arrest. The writer observes:

Actions like Young's should not be the subject of criminal liability, but the question here is whether they should be labeled justified or excused. Young is to be praised, not blamed, for what he did, and members of society would wish that others faced with similar situations requiring instant judgment would act as Young did. A moral assessment of Young's act would treat it as justified. ${ }^{\text {s }}$

This analysis incorrectly assumes that only a justification defense is appropriate for an actor who does what is morally right (given

tion of the doctrines of justification. It can be imposed, without alteration of existing statutes, under the general attempt provision. That is, attempt's subjective component of the rules of conduct would punish attempted violations of the rules of conduct that arose not only from attempted violations of the doctrines of criminalization but also from attempted violations of the doctrines of justification. A general attempt provision typically imposes liability when an actor engages in conduct that would be an offense "if the attendant circumstances were as he believes them to be." MPC $\$ 5.01(1)(a)$.

s4 One might argue that mistaken justification limited to reasonable mistakes, where the reasonableness is determined on a purely objective basis, also would provide invariant rules of conduct as effectively as objective justification. But the argument is misleading. Mistaken justification, so defined, is objective justification. If the mistaken justification defense is to be based upon the circumstances as they actually exist rather than upon the circumstances known to the actor, then the defense is in fact an objective, actual justification defense, not a mistake defense. A reasonable judgment on the actual facts is objective justification. On the other hand, if the mistaken justification defense is to be based upon the facts known to the actor, then it has been individualized in a way that makes it ineffective as a rule of conduct. When the actual circumstances come out at trial, an acquittal based upon such a mistaken justification might be taken to improperly condone conduct that in fact ought to be avoided in the future.

ss See MPC $\S \S 3.02,3.04-3.07$; and authorities cited in Robinson, 2 Criminal Law Defenses $\$ 184$ at 395 (cited in note 10).

36 Greenawalt, 84 Colum L Rev at 1919-20 (cited in note 22) (emphasis added). See also MPC Art 3; and Greenawalt, 84 Colum $L$ Rev at 1908. The case is reported at 11 NY2d 274, 183 NE2d 319 (1962). 
his view of the circumstances). But an excuse defense, even under current conceptions, also would judge the actor blameless.

The writer might respond, however, that it is Young's act that should be judged proper, not just Young. This is important because, as he explains, we want "others faced with similar situations [to] act as Young did." But the reasoning is flawed. It assumes that Young's act must be deemed justified, despite his mistake as to the actual circumstances, if future actors faced with similar situations are to be encouraged to act as Young did. The fact is that the future actor who believes he has come upon the mugging of an innocent youth will be encouraged to act by a rule of conduct that allows a (true) objective justification defense, the right to defend another from an unjustified attack. The future actor will not be deterred by the absence of a justification for the mistaken actor because he (the future actor) believes that the circumstances are such that his intervention actually is justified. That a mistake as to a justification is only excused is not of any relevance to him; he is actually justified, he believes. He may take some comfort in the fact that he nonetheless may be excused if his belief in his justification turns out to be mistaken-the existence of an excuse for a mistaken justification may thus be useful-but the rule of conduct need only protect actually (objectively) justified behavior in order to encourage future actors to act in situations where intervention appears to them to be justified. ${ }^{\text {t7 }}$

\section{Some Classification Challenges}

To complete this review of the more important aspects of current doctrine, and to sharpen the distinction between rules of conduct and principles of adjudication, consider which of the two functions-rules of conduct or principles of adjudication-are

\footnotetext{
${ }^{57}$ From the perspective of objective justification, it is entirely predictable that Greenawalt would conclude that the borders of justification and excuse are "perplexing," as the title of his article suggests. Greenawalt, 84 Colum L Rev at 1897 (cited in note 22). By defining justifications to include reasonably mistaken justifications, his attempt to distinguish justification and excuse is an attempt to distinguish mistaken justifications from excuses, which cannot be successfully done, I believe, because mistaken justifications are excuses. I believe that his conclusion, that the doctrine ought not systematically embody the justification-excuse distinction, must be qualified. The justification-excuse distinction is troublesome only if one adopts a subjective theory of justification, as Greenawalt does. Most if not all of his troublesome cases are clear and unproblematic under an objective theory of justification. In fact, one might conclude that the point he has demonstrated in his article is not the perplezing borders of justification and excuse, but rather that the perplexing borders created by the use of a subjective theory suggest a preference for the comparative conceptual clarity of an objective theory.
} 
served by the consent defense and the defense for de minimis infractions.

1. The consent defense.

Some instances of consent undercut the offensive nature of conduct and seem clearly part of the rules of conduct doctrines of criminalization. ${ }^{58}$ If the owner has given consent to enter his building, the entry is not trespass; it is not unlicensed. No special consent defense is required; the trespass offense prohibits only unlicensed entries. ${ }^{59}$ One might take a similar view of a football player who tackles another player during a game. The rules of conduct are not violated; the consent of the other player brings the assault within the rules of acceptable conduct. On the other hand, one might concede that consent relieves the actor of liability but argue that, in the case of the football assault, consent vitiates liability by justifying or excusing the assault.

But consent is clearly not an excuse. The football tackle is easily distinguishable from the excused attack of a madman or of one who mistakenly believes he is justified. Unlike these attacks, the tackle is fully acceptable, even desirable, conduct. We are more than happy to see the conduct repeated for as long as the consent remains in force.

The claim that consent is a justification, which has been made by at least one writer, ${ }^{60}$ is less obviously wrong. One could argue that the tackle is within the rules of conduct because the harm is outweighed by the greater good that derives from the game, and the game is possible only because of the "victim's" consent to the assault. The tackle is similar to other justifications, it could be argued, in that the circumstances render the otherwise unacceptable conduct acceptable.

But on closer scrutiny this, too, seems incorrect. Consent to the football assault is not a matter of justification but rather of non-criminalization, as with a consent defense to trespass. Justified

s8 For a description of consent defenses, see Robinson, 1 Criminal Law Defenses $\S 66$ at $307-11 \mathrm{nn} 2,15,20$ (cited in note 10). See also MPC $\$ 2.11$.

so See, for example, MPC \& 221.2(1) (defining criminal trespass to include the element that entry was "not licensed"; the consent of the owner would mean that this element could not be proven). Model Penal Code $\$ 2.11(1)$ confirms, perhaps unnecessarily, that consent is a defense when, as here, it "negatives an element of the offense."

'o See, for example, George P. Fletcher, A Crime of Self Defense: Bernard Goetz and the Law on Trial 19 (Free Press, 1988); and Fletcher, Rethinking Criminal Law at 705-06, 769 (cited in note 24) (arguing that consent operates as a justification rather than as a negative element of an offense); but see id at 707 (conceding some doubts). 
conduct is acceptable conduct, given the circumstances, but it is hoped that the justifying circumstances will not occur again. In contrast, the circumstances of consensual conduct evoke no such disapproval. The entire event leading up to the consensual tackle is acceptable and not something to be avoided in the future. Consistent with this difference in the acceptability of the episode is the fact that the creation of justifying circumstances ought to be and typically is a violation of the rules of conduct. ${ }^{61}$ In contrast, it is not a violation to hold a football game, to have consensual intercourse, or to engage in most other conduct that is acceptable because it is consensual.

\section{De minimis violations.}

Another doctrine that presents a classification challenge is the defense for a de minimis violation. The defense might be seen as refining the criminalization doctrines of the rules of conduct by limiting them to harms of sufficient seriousness. For example, unauthorized takings are prohibited by theft offenses. An actor who leaves a restaurant with an apple from a buffet after paying for the buffet, but in violation of the establishment's rule against removal of food, technically may violate the theft prohibition. ${ }^{62}$ Yet, the violation may be too trivial, or at least too close to the range of acceptable conduct, to warrant criminalization. One court reversed a conviction for the theft of three pieces of bubble gum for similar reasons. ${ }^{63}$

61 For a general discussion of liability for causing justifying circumstances, see Robinson, $71 \mathrm{Va} \mathrm{L} \mathrm{Rev} \mathrm{at} \mathrm{30-36} \mathrm{(cited} \mathrm{in} \mathrm{note} \mathrm{18).} \mathrm{For} \mathrm{a} \mathrm{bizarre} \mathrm{example,} \mathrm{see} \mathrm{Bailey} v$ Commonwealth, $229 \mathrm{Va}$ 258, 329 SE2d 37 (1985) (After angry verbal exchanges by telephone during which the defendant intentionally provoked the victim by calling his war hero, General George S. Patton, a homosexual, defendant told victim to arm himself and to wait on his porch because he was coming over; he then anonymously called the police to report a man waving a gun around, and the police officers who went to the house justifiably killed the victim when he threatened one of them, mistakenly believing that it was the defendant coming to shoot him; defendant's conviction for manslaughter was affirmed.).

${ }_{62}$ See State $v$ Nevens, 197 NJ Super 531, 485 A2d 345 (1984).

6s State v Smith, 195 NJ Super 468, 480 A2d 236 (1984). The court explains:

In the milieu of bubble gum pilferage the only cases more trivial are those involving two pieces or one. It is difficult to conclude the lawmakers would have intended the dividing line be drawn at three. It would seem the larceny of a single piece of bubble gum would fall within the statutory intendment of a trivial offense. Does then the theft of three pieces remove the actor's conduct from the scope of discretionary protection afforded [by the de minimis defense]? In a case involving substantially different conduct and attending circumstances perhaps it would; in this case it does not. 
On the other hand, one may ask: Is it that a de minimis violation is too trivial to be a violation of the rules of conduct, or is such a violation, in the words of the Model Penal Code, too trivial "to warrant the condemnation of conviction"? ${ }^{64}$ I believe the latter is the case. Stealing the bubble gum or taking the apple is a violation; the rules of conduct ought to tell an actor not to engage in such conduct. But if an actor does, the harm or evil is not sufficient to merit criminal condemnation. The rules of conduct are breached; persons ought not feel free to steal bubble gum or take apples in the future. But while de minimis infractions may violate the rules of conduct, they do not give rise to sufficient blameworthiness under the adjudicatory principles of blame to merit conviction.

\section{Summary}

To summarize, the doctrinal issues relating to the rules of conduct and the principles of adjudication, respectively, are:

\section{RULES OF CONDUCT}

\section{Doctrines of Criminalization}

Primary Prohibitions: Conduct and circumstance elements and criminalization mental elements of primary prohibitions

Secondary Prohibitions: Conduct and circumstance elements and criminalization mental elements of secondary prohibitions (secondary prohibitions include inchoate offenses and doctrines, such as complicity, that impute an objective element)

Obligations: Duties to act (upon which omission liability may be based)

Criminalization Refinements: Consent defenses

\section{PRINCIPLES OF}

\section{ADJUDICATION}

\section{Doctrines of Culpability}

Culpability mental elements of primary and secondary prohibitions

Result elements and causation requirements

Doctrines imputing culpability mental elements (e.g., voluntary intoxication) 
Doctrines of Justification

(Objective) justification defenses (defensive force justifications, public authority justifications, and lesser evils defense)
Doctrines of Excuse

Voluntary act requirement in commission offenses and capacity requirement in omission liability

Excuse defenses (e.g., insanity, immaturity, involuntary intoxication)

Mistake as to a justification excuse (including subjective requirements contained in justification defenses)

The rules of conduct are contained in the doctrines of criminalization and the doctrines of justification. The former doctrines include the conduct, circumstance, and criminalization mental elements of the primary prohibitions-which are typically contained in the definitions of specific offenses-and of the secondary prohibitions, which expand the law's prohibition to include attempting, assisting another in, or otherwise causing or furthering a violation of a primary prohibition. Refinements to the criminalization doctrines are contained in consent defenses. The doctrines of criminalization also include affirmative duties to act.

The doctrines of justification, consisting primarily of the justification defenses, admit a violation of a doctrine of criminalization but acquit an actor because his behavior remains within the rules of conduct. Such conduct is acceptable and may properly be repeated by others in similar justifying circumstances. Together, the doctrines of criminalization and justification provide society's statement of the rules of conduct.

The principles of adjudication include the doctrines of culpability and excuse. The doctrines of culpability attach blameworthiness, primarily by assessing whether the actor's state of mind with regard to his conduct and the circumstances surrounding the offense is such that the actor would normally be judged culpable for his violation. The existence of a harmful result from an actor's conduct may also increase the actor's blameworthiness. The doctrines of excuse determine whether there might be some abnormality in the particular actor or his situation that suggests blamelessness despite the presumption of blame created by the doctrines of culpability. 
In contrast to acquittals under the rules of conduct doctrines, which announce that the actor's conduct is not a violation of the rules, acquittals under the adjudication doctrines announce that the conduct continues to be a violation of the rules, although this actor is not to be punished for his violation. Similarly, the de minimis nature of a violation may so reduce an actor's blameworthiness as to render it too trivial for condemnation by criminal conviction.

Current doctrine's tendency to mix rules of conduct and principles of adjudication-in objective elements of offenses, in mental elements of offenses, in doctrines of imputation, in omission liability doctrines, and in general defenses-reflects its general failure to adequately distinguish these different functions. As Section III describes, the two functions have different doctrinal needs. Neither can be served effectively unless the underlying doctrines are formulated to meet its special needs. ${ }^{65}$

${ }^{65}$ The conceptualization proposed here provides at least part of the answer to a central question in criminal law theory. Fletcher suggests that the "unmet challenge of criminal theory consists in working out" the distinction between the "incriminating dimension of crime" and "the exculpatory dimension of justification and excuse." George P. Fletcher, The Unmet Challenge of Criminal Theory, 33 Wayne L Rev 1439, 1443 (1987). Fletcher's general challenge to develop a conceptual structure for criminal law doctrine is important and deserves the attention of serious criminal law theorists. But the particular formulation of his challenge may be misleading in its assumptions. Fletcher's challenge to define and distinguish the "incriminating dimension of crime" from the "exculpatory dimension of justification and excuse" assumes that the incriminating-exculpating distinction is the distinction of central importance and, further, that the conceptual structure should treat justifications and excuses together, as providing the "exculpatory dimension." These assumptions are, I believe, incorrect. As Fletcher notes with regard to intent and negligence as compared to accident and mistake, doctrines need only be stated as converse elements to change their character from inculpatory to exculpatory. Fletcher, 33 Wayne L Rev at 1443. The affirmative requirements of intent and negligence might be viewed as easily as the defenses of accident and mistake. Defenses, even general defenses of justification and excuse, similarly might be defined as negative elements of offenses. Given its manipulable nature, some additional refinement is needed before we can assume that the conceptual structure of criminal law ought to revolve around the inculpation-exculpation distinction, and that justification and excuse must be treated together as the "exculpatory dimension."

The central distinction for criminal law theory, proposed in this article, is not that between inculpation and exculpation but rather between rules of conduct and principles of adjudication. This conceptualization neither abandons the inculpation-exculpation distinction nor disagrees with the claim that the doctrines of justification and excuse may be viewed as analogous in a sense. It does suggest, however, that the inculpation-exculpation distinction is of secondary importance, and that the doctrines of justification and excuse "exculpate" in different ways. Violation of a doctrine of criminalization does not imply guilt; thus, a doctrine of justification does not "exculpate" from guilt, but serves only to rebut a presumption that an actor's conduct is in violation of the rules of conduct. The doctrines of justification and excuse are analogous, however, in that each serves to rebut a presumption that otherwise would establish one of the two prerequisites to liability-violation of the rules of conduct and an adjudication of blameworthiness for the violation. 


\section{The Need for Different Drafting Strategies for Rules of Conduct and Principles of Adjudication}

\section{A. Drafting Strategies}

There are many important differences between the rules of conduct and principles of adjudication functions of the criminal law. For example, as noted previously, rules of conduct make ex ante announcements while principles of adjudication allocate blame ex post for a violation of those rules. Other important differences are the audiences they address and the settings in which they are applied. The rules of conduct must be communicated to the general public in a form that all can understand and apply. They frequently must be applied in unanticipated situations with little opportunity for reflection or analysis. The main audience for the principles of adjudication, on the other hand, are the decisionmakers in the criminal justice process, primarily prosecutors, judges, and juries. ${ }^{66}$ These persons can be given specialized instruction for application of the governing principles. Further, the ex post nature of the blame inquiry permits time for research, reflection, and debate before the principles are applied. ${ }^{\text {t7 }}$ Finally, the nature and quality of the tasks are substantively different. The rules of conduct function is essentially descriptive, to describe for the public what they cannot, or can, or must do. The principles of adjudication function is essentially judgmental, to judge the blameworthiness of an actor who has violated a rule of conduct.

The differences between the two functions-ex ante versus ex post application, public versus specialized audiences, (potentially) immediate versus studied application, and descriptive versus judgmental nature of the functions-suggest the need to use different doctrinal forms in implementing the two functions. It is essential that the rules of conduct be easily accessible to the public and be in a form that maximizes clarity and ease of application. Besides simplicity and brevity, the use of an invariant standard with objective criteria is desirable to avoid the unpredictability, vagueness,

\footnotetext{
66 I say "main" audience because the general public will eventually hear of and must approve of the results generated by the principles of adjudication. On this important point I am unpersuaded by Dan-Cohen's arguments for "acoustical separation." See Dan-Cohen, 97 Harv L Rev at 634-37, 665-67 (cited in note 1) (arguing that the criminal law does and should provide "acoustic separation" between conduct rules and decision rules).

${ }^{6 z}$ See Paul H. Robinson, Legality and Discretion in the Distribution of Criminal Sanctions, 25 Harv J Leg 393, 400-07 (1988).
} 
and ambiguity that follow from individualized or subjective standards. ${ }^{68}$

The principles of adjudication call for a very different doctrinal form. Because the decisionmakers applying the principles of adjudication after the violation can be specially trained, allowed time for thoughtful application, and provided access to research and counsel, there is less need for simplicity and easy application. In fact, to take account of all the factors relevant to a judgment of blameworthiness, doctrines embodying principles of adjudication frequently must be complex, based on subjective criteria, and expressed in relatively vague and judgmental standards.

\section{B. Drafting Rules of Conduct}

Some illustrations from current law will confirm the need for different drafting strategies for rules of conduct and principles of adjudication. Consider current homicide provisions. To the lay reader, the California scheme, which is typieal of the codified common law approach, must be close to a meaningless jumble. For example:

[M]alice may be express or implied. It is express when there is manifested a deliberate intention .... It is implied, when no considerable provocation appears, or when the circumstances attending the killing show an abandoned and malignant heart . . . Neither an awareness of the obligation to act within the general body of laws regulating society nor acting despite such awareness is included within the definition of malice. ${ }^{60}$

The Model Penal Code homicide provisions are more simple but also confusing. The Code's language includes various culpable

\footnotetext{
e* In the definition of criminal risks, for example, the typical current formulation follows the Model Penal Code in individualizing the definition of the kind of risk that is prohibited by the rules of conduct. For example, a person is guilty of manslaughter "if he ... recklessly causes the death of another human being." MPC $\S \S 210.1(1), 210.3(1)(a)$. A person acts "recklessly" with regard to causing death when he creates or disregards "a substantial ... risk that [a death] will result from his conduct and the risk is of such a nature and degree that, considering ... the circumstances known to [the actor], its disregard involves a gross deviation from the standard of conduct that a [law-abiding person/reasonable person] would observe in the actor's situation." (emphasis added) In other words, the nature of the prohibited risk is defined in terms of the individual actor. Thus, the risks that are prohibited will be different for any given actor, depending upon "the circumstances known to him" and his "situation." Under such a subjective formulation, no actor can know with any certainty whether a given risk will be criminal for that actor to create. This is an example of a problem arising from the mixture of rules of conduct and principles of adjudication in a single doctrine. See text accompanying notes 38-49.

"D Cal Penal Code § 188 (West 1988).
} 
states of mind-"extreme emotional disturbance," "recklessness manifesting extreme indifference"-and describes degrees of homicide, none of which is required to state the rule of conduct. ${ }^{70}$ These factors serve only to establish the existence and degree of blameworthiness, functions of the principles of adjudication.

In contrasit to these inaccessible provisions, the rule of conduct at the heart of the offense of murder can be stated simply: "No person shall engage in conduct that creates a risk of death to another person." A similar simplicity and brevity can be achieved in drafting the rules of conduct for most offenses. Most forms of theft can be summarized in the prohibition, "No person shall take, exercise control over, or transfer property of another without consent of the owner." The rules prohibiting most forms of improper sexual conduct can be stated as, "No person shall engage in intercourse or make sexual contact with or expose his genitals to another person without such other person's consent." A second provision can define the conditions in which valid consent cannot lawfully be given..$^{71}$

The current formulation of generalized secondary prohibitions reflects the same obfuscation of relatively simple rules of conduct. The multi-page provisions on complicity and attempt, ${ }^{72}$ for example, can be replaced for the purposes of the rules of conduct with such simple statements as: "No person shall engage in conduct that assists another person in conduct that would be a violation [of the rules of conduct]"; "no person shall attempt to engage in conduct that would constitute a violation [of the rules of conduct]."

The justification doctrines illustrate a different problem under current codes. The defensive force provisions, for example, are commonly formulated as a series of detailed rules, exceptions, and exceptions to the exceptions for each of a variety of specific situations. ${ }^{73}$ While such detail may be useful and feasible in a principle of adjudication, thoughtfully applied by trained decisionmakers, it seems unrealistic to expect the average citizen to know these specialized rules, let alone to follow them in the threatening situations that call for the use of defensive force. The general requirements that defensive conduct be "necessary to protect the person or property" and "proportional to the harm threatened" are adequate

${ }^{70}$ See MPC $\S \S 210.2-210.4$.

${ }^{72}$ For an example of a provision delineating circumstances under which consent to sexual intercourse cannot be given, see MPC § 213.3(1).

73 See, for example, MPC $\$ \$ 2.06,5.01$.

${ }^{73}$ See, for example, MPC $\S \S 3.04(2), 3.05,3.06$. 
to convey the elements of justification and realistic in terms of what can be effectively communicated. ${ }^{74}$

To summarize, rules of conduct should be drafted separately from principles of adjudication, using invariant standards and objective criteria. In that form, the rules can be simple and brief. The brevity means that the rules can be widely disseminated. The simplicity means that they realistically can be taught to and understood by the general public. ${ }^{75}$

\section{Drafting Principles of Adjudication}

Separate documents, or "codes," for rules of conduct and principles of adjudication also could improve the accuracy and effectiveness of the latter. Many of the complex drafting forms that are problematic for rules of conduct are unproblematic, and frequently useful, in the context of principles of blame. For example, the complexity of the voluntary intoxication provisions ${ }^{76}$ would make them unworkable as rules of conduct, but in fact is entirely acceptable considering that such provisions actually operate as principles of adjudication. The language of the Model Penal Code causation provision-"too remote or accidental ... to have a [just] bearing on the actor's liability or on the gravity of his offense"77-similarly would be unacceptably vague and discretionary as a rule of conduct, but is appropriate because it actually serves as a principle of adjudication.

Many other doctrines currently adjudicating blame, however, use forms that are inappropriate for their function. Some use objective criteria or fail to adequately individualize an objective standard. In each instance, the form may be appropriate for a rule of conduct. One suspects that an insensitivity to the difference in the functions of rules of conduct and principles of adjudication is partly responsible for the inappropriately objective or invariant formulation.

\footnotetext{
${ }^{74}$ For authorities on and a discussion of these necessity and proportionality requirements, see Robinson, 82 Colum L Rev at 213-20 (cited in note 23).

${ }^{75}$ Grammar school and high school programs might study the rules of conduct, with discussion of illustrative applications to common situations. While against our tradition of complex codes this proposal may sound impractical and unrealistic, rules of conduct that are simply stated and easily read could be published in a government pamphlet for wide distribution.

${ }^{76}$ See, for example, MPC § 2.08 .

${ }^{77}$ MPC $\S 2.03(2)(b),(3)(b)$.
} 
A modern immaturity defense, for example, typically is available to an actor at or below a specific age. ${ }^{78}$ Such an age cut-off formulation of the defense makes it easy to apply, but results in a failure to excuse an older actor who is as immature as a typical under-age actor and for whom, consequently, we have reduced normative expectations. In State $v$ Jamison, for example, the defendant was denied an immaturity defense, despite his "mental age" of 11.7 years, because his chronological age of seventeen put him over the statutory cut-off for the immaturity defense. ${ }^{79}$ An immaturity defense formulated as an age cut-off also creates the converse problem of understating our normative expectations for the fully mature but underage actor. As long as the actor's chronological age is less than the statutory cut-off, the excuse will obtain, even if he is sufficiently mature to be reasonably expected to avoid the violation. Thus, application of the defense is reduced to timing disputes. In Parker $v$ State, for example, the defendant noted that he committed the offense at 9:45 a.m. on his birthday but that he was not born until 12:50 p.m. that day. Thus, he argued, he had not yet reached the cut-off age. ${ }^{80}$

Objective, easy to apply criteria are critical for a rule of conduct but are not necessary for a principle of adjudication. It is not that such criteria are inherently problematic; ease in application is always a virtue. Rather, objective criteria can be troublesome when incorporated into principles of adjudication because assessments of blameworthiness frequently require subjective or discretionary criteria. In the case of the immaturity excuse, for example, a defense that looked to the actor's actual degree of immaturity would be more consistent with inquiring into moral culpability. If a concession to easier application is needed, it could be made by using rebuttable presumptions, rather than the essentially irrebuttable

${ }^{28}$ See authorities cited in Robinson, 2 Criminal Law Defenses $\S 175$ at 321-24 n 1 (cited in note 10).

79 23 Wash App 454, 597 P2d 424 (1979), affd, 96 Wash 2d 794, 613 P2d 776 (1979). In some jurisdictions, the insanity defense is formulated broadly enough to cover such a case. Model Penal Code § 4.01, for example, uses the phrase "mental disease or defect" (emphasis added). On the other hand, while mentally retarded actors may be excused under this formulation, it is not clear that a defense would be available to the actor who is immature simply because of an isolated childhood or other socialization disorders.

${ }^{80} 61 \mathrm{Md}$ App 35, 484 A2d 1020 (1984). The court in Parker rejected the defendant's claim, holding that the defense should be applied according to the defendant's birthday but not his birthhour. Of course, this hardly alters the arbitrariness of the defense or the irrationality of its results. Under the court's rule, Parker would have had the defense if he had committed the violation nine hours and forty-six minutes earlier or if he had been born eleven hours and eleven minutes later. 
presumptions contained in current formulations. That is, an actor below a given age might be presumed immature unless the prosecution proved otherwise, and an actor above a given age might be presumed mature unless the defense proved otherwise. There is some precedent for such a rebuttable presumption approach in state codes and at common law. ${ }^{81}$

Like the misguided use of objective criteria, another common flaw in principles of adjudication is the failure to individualize an objective standard. The rejection of an individualized standard is appropriate for rules of conduct, but such individualization is desirable for principles of adjudication. For example, some individualization of the negligence standard is important to a proper assessment of an actor's blameworthiness. It is simply not true that we expect the same thing from all persons in a given situation. It may be culpable negligence for an ordinary person to block an emergency vehicle at a critical moment; the same behavior may not be culpable for a blind person. It may be culpable negligence for an ordinary person to permit a child to swim in the ocean after a big meal; but it may not be culpable negligence for a twelve year-old babysitter. The father who leaves the stove on while taking his just-burned child to the hospital and the driver who loses control of his car when a passenger tells him of his son's unexpected death also illustrate the need to individualize the reasonable person standard, if it is to accurately reflect the normative expectations by which the community assigns or withholds blame.

The failure to individualize the reasonable person standard in the definition of negligence infects many other doctrines of adjudication, including those that allow a defense for a "reasonable" mistake or belief. A "reasonable" belief (and by analogy any other term modified by the word "reasonable") is defined as a non-negligent belief..$^{82}$ Thus, a "reasonableness" standard incorporates the flaws of the negligence definition. The failure to properly individualize the negligence definition, then, will overstate our normative

\footnotetext{
82 In several states, the fact that the defendant is younger than a specified age creates only a rebuttable presumption of immaturity. See Ariz Rev Stat Ann $\$ 13-501$ (West 1978) (under 14); Cal Penal Code $\S 26(1)$ (West Cum Supp 1988) (under 14); Nev Rev Stat chs 194.010(1)-(2), 193.210 (1977) (between ages of 8 and 14); 21 Okla Stat Ann $\S 152(1)-(2)$ (West 1983) (between 7 and 14); SD Cod Laws Ann $\$ 22-3-1$ (1)-(2) (Cum Supp 1987) (between 10 and 14); Wash Rev Code Ann § 9A.04.050 (West 1977) (between 8 and 12). This also was the approach of the common law. Children under seven were given a defense; children over seven but under twelve (or fourteen) were entitled to a presumption of immaturity, but the presumption could be rebutted. See William Blackstone, 1 Commentaries on the Laws of England 452-53 (U Chicago, 1979).

s2 See MPC § 1.13(16).
} 
expectations of an actor in applying the defenses of reasonable mistake of law, reasonable mistake as to a justification, or reasonable resistance to duress. ${ }^{83}$

These improper formulations of principles of adjudication have a second order effect that in some instances may be even more harmful than their primary failing. Because the culpability doctrines of negligence and recklessness are unreliable in assigning culpability, current law understandably tends to avoid assigning liability for negligent and reckless behavior or for risk-creation offenses, which tend to rely upon the definitions of negligence and recklessness. ${ }^{84}$ But this leaves unprohibited and unpunished conduct that few would dispute ought to be prohibited and punished..$^{85}$

ss Admittedly, criminal law theorists have not yet been able to fashion a workable principle that distinguishes those characteristics of the actor that should be taken into account from those characteristics that should not. But the treatment to be accorded certain characteristics is relatively clear. As the Model Penal Code commentary notes with regard to determining negligence:

If the actor were blind or if he had just suffered a blow or experienced a heart attack, these would certainly be facts to be considered in a judgment involving criminal liability, as they would under traditional law. But the heredity ... or temperament of the actor would not be held material in judging negligence .... The [Code's use of the phrase "in the actor's situation"] is not intended to displace discriminations of this kind, but rather to leave the issue to the courts.

MPC \& 2.02(4), comment 242 (footnotes omitted). The literature provides further examples of characteristics that should be considered under a reasonable person standard. See, for example, George P. Fletcher, The Theory of Criminal Negligence: A Comparative Analysis, $119 \mathrm{U} \mathrm{Pa}$ L Rev 401, 429 (1971) (duress, insanity, or other conditions rendering conduct involuntary and thus blameless); Oliver Wendell Holmes, Jr., The Common Law 109 (Little, Brown, 1945) (blindness, infancy, and insanity); and Glanville L. Williams, Criminal Law: The General Part \$ 36 at 101-02 (Stevens \& Sons, 2d ed 1961) (admitting the possibility of a system that would consider education, opportunities, and means of knowledge; noting that courts have considered age, sudden blows to the head, sudden manifestations of neurosis, and unforeseeable consequences of intoxicants).

Writers also have identified characteristics that should not be considered in individualizing the reasonable person standard. See, for example, Fletcher, $119 \mathrm{U} \mathrm{Pa} \mathrm{L}$ Rev at 433 ("temperament, intellect, and education"); Williams, Criminal Law § 36 at 101 (noting the impropriety of considering capacity for imagination and foresight; noting that in general courts have not embarked on a course of including and excluding certain personal characteristics). There seems little doubt that such characteristics as maliciousness, meanness, deceptiveness, destructiveness, or dishonesty do not alter our normative expectations and should not be taken into account.

84 For a discussion of other such distortions and counter-distortions of the doctrine, see note 87.

ss One would think, for example, that there would be little dispute that persons should not create a risk of explosion that would destroy a warehouse or create a risk of fire that would destroy a residence; yet current doctrine commonly does not prohibit the creation of such risks. See, for example, Commonwealth v Simkins, $297 \mathrm{~Pa}$ Super 258, 443 A2d 825 (1982) (the storing of a drum of acetone sealed only with paper towels, which created risk of fire to the residence in which it was stored, was insufficient to establish the risk required for 


\section{Proposals}

Two sorts of difficulties with current doctrine have been noted. First, because of formulations and codifications that are insensitive to a doctrine's function-of either defining and communicating clear and usable rules of conduct or articulating principles that accurately adjudicate an actor's blameworthiness-much of current doctrine fails to effectively perform its function. A second difficulty arises from the failure of current doctrine to distinguish rules of conduct acquittals from principles of adjudication acquittals, a failure that undercuts the prohibitions of the rules of conduct. ${ }^{88}$ The starting point for solving both problems is to draft laws that recognize and reflect the distinction between rules of conduct and principles of adjudication.

The first and most important reform proposal, then, is the formulation and drafting of independent codes or parts of a code for rules of conduct and principles of adjudication to reflect their two distinct functions. The rules of conduct should be stated in simple, brief, and commonly understood language that can be widely disseminated. The principles of adjudication should be made as com-

conviction for risking catastrophe under $18 \mathrm{~Pa}$ Cons Stat Ann § 3302(b) (Purdon 1983)). See also NJ Stat Ann § 2C:17-2(c),(e) (West 1982) (requiring risk of damage to ten or more habitations or to a building that normally would contain fifty or more persons at the time of the offense).

se To prevent such undercutting, many substantive provisions are altered to minimize the acquittal of violators, but such distortions create their own set of injustices. For example, Judge Leventhal argues against giving a defense for even a reasonable mistake as to a justification as follows:

We should refuse to cut away and weaken the core standards for behavior provided by the criminal law. Softening the standards of conduct rather than ameliorating their application serves only to undermine the behavioral incentives the law was enacted to provide.

United States v Barker, 546 F2d 940, 972 (DC Cir 1976) (Leventhal dissenting) (footnote omitted). Lord Coleridge's opinion in Dudley and Stephens makes a similar point. The defendants were denied both a lesser evils justification and a mistaken justification excuse for their killing of a dying cabin boy in order to consume his blood and thereby live long enough to be rescued from their drifting lifeboat.

It is not needful to point out the awful danger of admitting the principle which has been contended for [of allowing a defense for Dudley and Stephens' killing of the cabin boy].... [I]t is quite plain that such a principle once admitted might be made the legal cloak for unbridled passion and atrocious crime.

The Queen $v$ Dudley and Stephens, 14 QBD 273, 287-88 (1884). See also Russell v State, 219 Ala 567, 122 S 683, 685 (1929), quoting Street v Sinclair, 71 Ala 110, 115 (1881) (in discussing the prohibition against the use of violence to repossess property the court notes: " 'But he proceeds at his own peril if he commits the slightest assault, or other breach of the public peace, for, if individuals were thus allowed to redress their own private injuries, the peace of society and good order of government would cease' "). For further illustrations of such compensating distortions, see note 87 . 
plex or discretionary as is necessary to properly capture the community's evaluation of blameworthiness, without the constraints that might be imposed on a document designed for unsupervised, lay application.

The drafting of an independent "Code of Conduct" and "Code of Justice" also would allow the rules of conduct to be kept invariant without depriving actors of merited excuses. If an excuse is appropriate, it can be made available through a separate doctrine adjudicating blame. Independent codes also would permit the doctrines of adjudication to be more individualized without fear that such individualization would undercut the rules of conduct. An acquittal based upon no violation of the rules of conduct would announce approval of the conduct and reaffirm the rule and its scope. An acquittal based upon an absence of blame would announce disapproval of the conduct and similarly reaffirm the rule and its scope. ${ }^{87}$

A second kind of reform made possible by distinguishing and segregating the two functions lies in formulating procedures for arrest, charging, trial, and disposition. For example, the arrest and charging process might employ the distinction by using probable cause for a violation of a doctrine of criminalization as the standard for arrest, leaving justification and principles of adjudication issues for post-arrest adjudication.

The most important procedural reform might be the introduction of a different verdict for no-violation acquittals than for noblame acquittals. Such verdicts-"no violation" and "blameless violation"-would clearly indicate whether this actor's conduct is approved or disapproved, so that the public could properly guide its future conduct. Such a verdict system is simply an expansion of the distinction currently recognized by the "not guilty by reason of

\footnotetext{
${ }^{87}$ One additional benefit that might be derived from distinguishing no-violation acquittals from no-blame acquittals is that legislators (and courts) would no longer be inclined to distort doctrine in order to avoid acquitting violators and, in turn, to adopt liberalizing counter-distortions. For example, if non-negligent violations could be exempt from liability without undercutting the rules of conduct, by distinguishing such no-blame acquittals from no-violation acquittals, then it might be feasible to provide a broader, more individualized definition of negligence that more properly mirrors our culpability notions. If a more accurate and reliable definition of negligence were adopted, it might be possible, in turn, to criminalize more instances of risk-creation and to more frequently assess culpability for negligent violations. And with these reforms in place, it might in turn be more possible to abolish the use of strict liability. The same need for chains of reform exists in the troublesome areas of omission liability, justification defenses, and excuse defenses.
} 
insanity" verdict. The verdict admits a violation of the rule of conduct but judges the actor blameless for it. ${ }^{88}$

One also might wish to rely on the rules of conduct/principles of adjudication distinction in allocating the burdens of proof at trial. Given the primarily objective criteria of the rules of conduct, it is reasonable to expect the state to prove a violation. The doctrines of adjudication, however, given their focus on the individual characteristics or the state of mind of the defendant, are more easily proven by the defendant. ${ }^{89}$ One might reach the same conclusion by arguing that because the rules of conduct are designed primarily to guide the conduct of future actors, their application is a function more properly shouldered by the state than by the defendant. Because the principles of adjudication concern the blameworthiness of a particular defendant, who admittedly has violated the rules of conduct, disproving blameworthiness might properly be the burden of the defendant rather than the state.

On the other hand, the conceptualization proposed here might suggest that the doctrines of criminalization and culpability ought to be distinguished from the doctrines of justification and excuse in allocating the burden of proof. The former doctrines are necessary to create at least a rebuttable presumption of the two minimum requirements necessary for criminal liability-violation of the rules of conduct and blameworthiness for so doing. The latter

ss I have made a similar proposal for a special verdict in Robinson, 82 Colum $L$ Rev at 290 (cited in note 23). Greenawalt argues that a general verdict is useful to preserve the jury's right to disagree with the law and to follow its own intuitive judgments of justice. Greenawalt, 84 Colum L Rev at 1900-01 (cited in note 22). Whether or not one agrees with this function of general verdicts, the argument does not undercut my proposal. Providing two acquittal verdicts-acquittal based upon no violation of the rules of conduct and acquittal based upon no blame for a violation-restricts very little the jury's ability to act upon its intuitive judgment. The concepts of and the distinction between rules of conduct and principles of adjudication are as intuitively recognized and understood as the distinction between harm and blame. Such verdicts, however, would require a jury to determine whether the group shared the same judgment on this basic distinction-no violation versus blameless violation-but this would seem a valuable effect.

Note that the objections to the two-verdict system proposed here apply equally to the "not guilty by reason of insanity" verdict; yet that verdict seems workable in practice. It does not appear to unacceptably restrict the jury's right to follow its own intuitive judgments of justice.

89 This corresponds with the general evidentiary rule that the party in the best position to prove an issue-i.e., with best access to the information-should have the burden of proving it. See, for example, LaFave and Scott, Criminal Law $\$ 1.8(\mathrm{c})$ at 52 (cited in note 36); Edward W. Cleary, ed, McCormick on Evidence $\$ 337$ at 950 (West, 3d ed 1984) (discussing but criticizing this rationale for allocation); and State $v$ Savoie, $67 \mathrm{NJ} 439,341$ A2d 598, 611 n 8 (1975) (invoking this rationale in allocating to defendant the burden of production on issue of mistake). 
serve to rebut the presumptions and, typically, arise in fewer and in unusual cases. Therefore, the burden of proving the former doctrines and establishing a rebuttable presumption of liability might properly be allocated to the state; the burden of proving the latter doctrines and rebutting the presumption might be allocated to the defendant. ${ }^{90}$

While there are at least two alternative theories for rational allocation of the burdens of proof, the rules of conduct/principles of adjudication distinction is not useful in choosing between the two theories. The difficulty stems not from the conceptualization but rather from the failure of evidence theory to settle on the appropriate criterion for allocating burdens of proof. ${ }^{91}$

Shifting some of the current burdens of proof may be important to overcoming legislative resistance to the full range of doctrines of blame. Reforms that seek to broaden exculpation of the blameless-for example, the shift from strict liability offenses to negligence, the greater individualization of the reasonable person standard in negligence, and the recognition of an excuse for a reasonable mistake of law-may be politically unacceptable without allocating to the defendant one or more of the burdens of proof on such issues. From a defendant's perspective, the advantages from a broadening of the doctrines of blame frequently would outweigh the disadvantages of being required to shoulder the burden of proof. Requiring the defendant to prove non-negligence, for example, would be an improvement, from the defendant's perspective, over strict liability's irrebuttable presumption of negligence.

The rules of conduct/principles of adjudication distinction also might be useful after trial, at the disposition stage. For example, it may be advisable to attach non-punishment conditions upon or maintain civil jurisdiction over a defendant acquitted under a doctrine of blame adjudication where there is a continuing danger he

90 This corresponds with the general evidentiary rule, which has a certain commonsense appeal, that the party benefiting from an issue should have the burden of raising and making some minimal showing on it. See McCormick on Evidence $\$ 337$ at 952 (cited in note 89) (civil rules); see also MPC $\S 1.12(4)$ (employing this rule where issues other than an "element of an offense" are at issue).

92 Compare Ronald J. Allen, Mullaney v Wilbur, The Supreme Court, and the Substantive Criminal Law-An Examination of the Limits of Legitimate Intervention, 55 Tex L Rev 269 (1977); and John C. Jeffries, Jr., and Paul B. Stephan III, Defenses, Presumptions and Burden of Proof in the Criminal Law, 88 Yale L J 1325 (1979). Of course, one might want to use different theories in allocating different burdens of proof-the burden of going forward, the burden of production, and the burden of persuasion. 
will violate the rules of conduct. ${ }^{92}$ Where the acquittal is based upon a finding of no violation of the rules of conduct, there is by definition no reason to avoid repetition of the conduct in the future and therefore no reason for continuing criminal or civil jurisdiction.

Still another reform this conceptualization might facilitate would be to vary the level of adherence to the legality principle. Under the legality principle, criminal liability and punishment can be based only upon a prior, written offense that is expressed with adequate precision and clarity. ${ }^{93}$ One is inclined to demand the greatest precision in the primary prohibitions of the doctrines of criminalization, for these contain specific rules of conduct. One might demand slightly less precision in a secondary prohibition. Secondary prohibitions also must communicate a clear rule, but much of the required notice is already communicated by a clear primary prohibition. That is, one can give sufficient notice by advising actors that they must not only avoid the conduct described by the primary prohibitions but also must avoid aiding it, attempting it, and agreeing with or soliciting others to attempt it.

One might tolerate still less precision in the doctrines of justification, which contain the permissive portion of the rules of conduct; an actor is not required to perform this conduct but rather is authorized to if she chooses. Indeed, reduced standards of precision may be necessary for justifications. The situationally-dependent nature of these doctrines means that, to remain communicable rules of conduct, justifications cannot be stated with great specificity.

The nature of the doctrines adjudicating blame suggests a still lower level of precision. The doctrines of culpability and excuse play no part in stating the rules of conduct; an actor is not to guide her conduct by the formulation of these doctrines. In fact, many excuse defenses presume an actor's incapacity to guide her conduct in accordance with the announced rules. Further, the individualized nature of the doctrines of excuse suggest that they can only be described in broader, more general terms. More specific, fixed criteria would not adequately take account of the full range of individual characteristics that might be relevant to blameworthiness.

22 The most obvious example is the dangerous mentally ill offender. There may be other instances, however, where a non-punishment condition or restriction is appropriate. See Robinson, 82 Colum L Rev at 285-90 (cited in note 23).

ss See Robinson, 25 Harv J Leg at 393-94 (cited in note 67). 
Different rationales support application of the legality principle to doctrines of adjudication than to the rules of conduct. Notice is the primary rationale for rules of conduct. Without notice of what conduct is prohibited, required, and permitted, there is no basis on which to condemn an actor for a violation and little hope that the criminal law can gain future compliance. For principles of adjudication, the rationales are different. Wide dissemination of the principles of adjudication is not necessary either to condemn violation of or to gain compliance with the rules of conduct. Instead of notice, the legality rationales include: increasing uniformity of application to similar cases, limiting the potential for abuse of discretion, and minimizing the improper delegation of criminalization authority from the legislature to the courts. These rationales are furthered by the codification of principles of adjudication. To demand great precision in the written principles is to compel a false precision that will distort the assessment of blameworthiness.

One final use of the rules of conduct/principles of adjudication distinction might lie in taking account of the frequently conflicting demands of utilitarian and just desert goals in determining the distribution of criminal liability and punishment. The utilitarian goal is the elimination or at least the reduction of future crime; the just desert goal is the imposition on an offender of that degree of punishment deserved for a past crime. For example, one might rely primarily on desert concerns in formulating the principles of adjudication, ${ }^{94}$ for the issue of blameworthiness is the primary concern of the adjudication principles. ${ }^{95}$ The rules of conduct, in contrast, might be formulated to give greater deference to utilitarian concerns. At the very least, the rules of conduct/principles of adjudication distinction may in some way, perhaps in conjunction with other distinctions, provide a greater opportunity to devise a principled distribution of criminal liability; this would be a great improvement over the nebulous and potentially deceptive "balancing" or "mixing" of utilitarian and desert purposes that is currently fashionable. ${ }^{96}$

\footnotetext{
94 Some writers argue that utilitarian concerns support the distribution of liability according to desert. See Louis Michael Seidman, Soldiers, Martyrs, and Criminals: Utilitarian Theory and the Problem of Crime Control, 94 Yale L J 315 (1984).

${ }^{95}$ Desert theorists might well have much to say about what should and should not be criminalized. My claim here is simply that having control of the principles of adjudication would be more important to furthering desert concerns.

98 See Paul H. Robinson, Hybrid Principles for the Distribution of Criminal Sanctions, $82 \mathrm{Nw}$ U L Rev 19, 19-22 (1987).
} 
Ultimately, criminal law doctrine that distinguishes rules of conduct from principles of adjudication can more accurately and fully differentiate conduct that society believes ought to be announced as criminal from conduct that it believes ought not, and between actors whom society feels ought to be condemned for a violation of the rules from those whom it would not condemn. 
